\title{
LOS MUDÉJARES CONTESTANOS EN EL SIGLO XIII
}

\author{
JOAQUIN NAVARRO REIG
}

Centre d'Estudis Contestans

In memoriam frater meum

\section{INTRODUCCIÓN}

Con el avance del proceso repoblador hacia tierras meridionales, los cristianos van a encontrarse con una situación que les resulta nueva; deben, compartir su existencia con una masa numerosa de población musulmana. La convivencia de ambos grupos en un régimen de tolerancia mutua ha dado lugar a la acuñaciòn del término mudejarismo, aspecto éste que ha condicionado profundamente toda nuestra historia futura.

Isidro de las Cágigas (1948-9, p. 9-13, passim) pretende explicar su origen en la influencia política de los consejeros mozárabes de los monarcas cristianos. Excelentes conocedores del problema serán los que crearán el concepto sociológico y humano del mudéjar, recogiendo para ello una de las concepciones más hábiles de sus enemigos musulmanes, la doctrina coránica de protección, es decir la «dimma».

La valoración del fenómeno mudéjar no debe quedar reducida a su aspecto estrictamente religioso o racial, sino que donde alcanza su verdadera dimensión, no siempre comprendida, es en la problemática de las relaciones sociales intercomunitarias.

La raíz del mudejarismo valenciano hay que buscarla en las propias características de la conquista del reino. La caída de Valencia, Xátiva y Biar ante la presión armada aragonesa determinó a los consejos locales musulmanes a buscar una salida negociada a la crisis que les resultase lo más favorable posible. La corona, por su parte, interesada en atraerse a la población autóctona, más que enfrentarse con ella, le otorgó favorables capitulaciones 
a los residentes musulmanes que optasen por permanecer en sus hogares, lo que les permitía conservar una extensa autonomía a todos los niveles, después de la conquista. Gracias a estas capitulaciones que les concedian un amplio margen de libertad, muchos de los antiguos moradores decidieron permanecer en sus casas, conservando una parte de sus bienes; tan sólo una minoría, generalmente la clase más influyente, optaría por el exilio a tierras meridionales.

La revuelta de Al-Azracq imprimió un giro importante a la situación. Una parte importante de su población fue obligada a abandonar el reino y en su lugar empezaron a asentarse las primeras familias cristianas procedentes de los dominios aragoneses del norte y que abren, así, una nueva fase de mudejarismo interno.

Durante las primeras décadas, la dualidad cristiano-mudéjar llega a alcanzar un estado de equilibrio, dominando políticamente los primeros y numéricamente los segundos. Este equilibrio pronto se rompió en favor de los cristianos que impusieron su personalidad en este confuso mosaico de población (Barceló 1984, 92).

Lentamente la situación va evolucionando en el sentido de un mayor intervencionismo cristiano, alentado por la propia Iglesia de Roma y por la mentalidad de cruzado europeo. De este modo, los antiguos órganos municipales se fueron debilitando y perdiendo importancia. El contenido de aquellas favorables capitulaciones era una y otra vez pisoteado por unos y otros, convirtiéndose en letra muerta.

Esta degeneración de la situación originaria estimuló la emigración hacia el consolidado reino de Granada de las clases más relevantes de la sociedad mudéjar y tras éstos, siguieron su ejemplo, otros grupos importantes. La crisis económica y la propia política real incentivaron la emigración. Muchos perdieron o malvendieron sus tierras con lo que desaparecieron los únicos lazos que les ataban al solar de sus antepasados. Con la pérdida de sus propiedades, los mudéjares perdieron su independencia, y con la de sus líderes, su identidad cultural y religiosa que entró, a partir de ahora, en una fase de fanatismo cerrado (Torres Fontes 1961, 57-81). Acosados por los cristianos se verán obligados a vivir en un estado latente de rebeldía que será aprovechado por algún líder musulmán, más o menos improvisado, en su propio interés.

El peligro que esto representaba para la seguridad del Reino hizo que la corona no encontrase otra solución que su expulsión en masa, habida cuenta de que nadie pensaba, como factible, que esta minoría se convirtiera al cristianismo por el simple hecho de serlo sus señores, mas si tenemos en cuenta 
que la adopción de una determinada creencia no sólo tiene connotaciones puramente religiosas, sino que engloba todo el mundo cultural del invasor, o como diría R. I. Burns, del colonizador.

La medida, aunque lógica, era inapropiada en esos momentos. El problema radicaba en que no se disponía de los suficientes recursos humanos para sustituirles, por ello, los nobles, siempre atentos a defender sus intereses, adoptarán una postura de rechazo a la medida real de expulsión y la resistirán, amparándose, no sin razón, en las graves consecuencias económicas que dicha decisión conllevaba.

Sea por la oposición nobiliaria, sea por la imposibilidad real de ponerla en práctica, lo cierto es que la mayoría de los mudéjares permanecieron en sus hogares e iniciaron un largo proceso de relaciones con los cristianos en el cual van a ser los perdedores, ya que la fórmula de respeto mutuo habia muerto. Las causas pueden ser debidas a una falta de comprensión del problema mudéjar por parte de los cristianos, a lo que se sumaría una incomprensión del cambio de coyuntura, surgida tras la conquista, por parte de los mudéjares (Fernández y González 1866, 101 y ss.)

\section{ESTADO DE LA CUESTIÓN}

Resultaría del todo problemático el pretender estudiar tan peculiar fenómeno si nos ciñéramos exclusivamente a los datos proporcionados por la documentación local o foránea sobre el mudejarismo contestano. El Archivo de la Corona de Aragón cuenta con una vasta documentación al respecto (Burns 1981a, 453-498), pero se refiere a todo su conjunto y, por tanto, muy poco nos afecta directamente; por otra parte desconocemos los términos de la cartapuebla fundacional del arrabal contestano por Jaime I. Estas limitaciones obligan a aprovechar la documentación disponible procurando encuadrarla en el contexto general.

Sobre las consecuencias de la conquista cristiana para los mudéjares valencianos, las opiniones de los historiadores se han polarizado en torno a dos posiciones. Para Guichard $(1980,65)$ la ocupación cristiana del Reino de Valencia significó un duro revés, a todos los niveles, para los musulmanes valencianos, degradándose mucho más con el paso del tiempo.

Por otro lado, Roca Traver (1952, 115-208), Gual Camarena (1949, 165199), Burns $(1981,239-266)$, etc. consideran que la conquista no introdujo ningún cambio significativo en la vida de este pueblo sometido que pudo seguir libremente disfrutando de una situación de privilegio que resultaba envi- 
diable para gran número de cristianos. Con el tiempo este trato a favor irá siendo sustituido por otro de opresión, pero para ello habría que remontarse a las futuras generaciones. Creemos que las siguientes palabras de Barceló Torres (1984, 93) expresan claramente la realidad del momento: «La sociedad musulmana colonizada por catalanes y aragoneses en el siglo XIII fue objeto siempre del proselitismo cristiano. Desde las predicaciones hasta las ventajas económicas por la conversión, el musulmán caminó irremediablemente al bautismo forzado. Los acontecimientos le llevaron hacia el cristianismo y contra él. Sin embargo, el desarrollo de estos acontecimientos no fue uniforme, como era su distribución geográfica y poblacional. Alli donde constituian una minoría encerrada tras unos muros, las tensiones religiosas fueron mayores. Por el contrario, donde eran habitantes exclusivos su libertad religiosa pudo manifestarse de una forma más abierta y en cierto sentido más natural'».

Basan sus razones los defensores del continuismo en el estudio de las cartas-puebla, muchas de ellas publicadas por Gual Camarena, otorgadas a muchas comunidades mudéjares y en las que se observa un trato a favor, mucho mejor que el que disfrutaban durante la dominación almohade, pero «a pesar de ello, o quizá por esas circunstancias, y a pesar de la asimilación reciproca y pacifica convivencia de cristianos y mudéjares, una aversión profunda dividía a ambos pueblos. Este sentimiento fue, no sólo, más allá de actitudes convencionales o expresiones de desprecio mutuo, sino incluso más allá de la hostilidad que se podía esperar que provocarían las diferencias religiosas; refleja un antagonismo básico de culturas en una posición clásica de conflicto. Tal antagonismo tomó, finalmente, forma violenta en las revueltas y asaltos a las aljamas mudéjares que afectaron a todo el reino de Valencia hacia 1275. Estas revueltas, antes limitadas a unos pocos brotes localizados, y en conexión con el levantamiento de los mudéjares valencianos, se exten. dieron por todo el pais, de Peñiscola a Cocentaina, durante varios meses, produciendo muchos años y tomando forma de levantamiento contra la política mudéjar de la monarquía” (Burns 1981a, 456).

Consideramos, en honor a la verdad, que la documentación oficial puede reflejar una situación que no siempre coincide con la realidad, por tanto somos de la opinión que desde el momento de la repoblación de las tierras conquistadas, los mudéjares debieron de empezar a sufrir los efectos negativos de su capitulación.

\section{CONTEXTO CONTESTANO}

La falta de referencia expresa en las crónicas sobre la conquista de Cocentaina hace preveer que su dominación no se produjo tras un enfrentamiento 
armado, sino después de una serie de contactos que desembocaron en su capitulación, previsión lógica si se tiene en cuenta la desaparición del poder central musulmán. Los musulmanes contestanos, abandonados a su suerte, faltos de recursos e incapacitados para reaccionar, ven en la capitulación la única salida viable a su delicada situación (Guichard 1980, 75).

La capitulación representa, para Gual Camarena (1949, 166), un compás de espera. Los mudéjares se consideran vencidos, pero no sometidos, $\mathrm{y}$, por tanto, a la menor oportunidad se levantarán en armas contra los invasores (Furió y García 1983, 34).

Como consecuencia de las capitulaciones, la corona se avino a que los musulmanes contestanos tuvieren la facultad de poder elegir entre el exilio voluntario o permanecer en sus hogares «manteniendo intactas sus costumbres religiosas, jurídicas, sociales y de política locals (Burns 1981a, 453). Desgraciadamente la desaparición de la carta-puebla de la morería de Cocentaina nos impide hacer una valoración justa de su verdadera dimensión.

Los años anteriores a la primera revuelta debieron de discurrir al igual que la etapa anterior. Los mudéjares contestanos conservarían sus autoridades locales y su organización propia tal como la habían disfrutado hasta la fecha, incluso es posible que la tenencia de su castillo continuase en manos de su antiguo alcaide, a cambio de un juramento de fidelidad.

El alzamiento de Al-Azracq imprimió un giro radical a la situación. La conquista efectiva pasaba por el establecimiento de repobladores en estas tierras de frontera, los cuales empiezan a llegar a partir de 1248. Su número resultó insuficiente para el control de tan vasto territorio, más aún si tenemos en cuenta que su número real fue mucho menor. La llegada de éste y otros contingentes sucesivos se debió al señuelo de las concesiones territoriales que el rey otorgaba a todo aquél que estuviese decidido a establecerse en la villa. De esta forma se van a repartir las propiedades yermas o sin dueño y otras propiedades de las aljamas o residentes musulmanes. El cambio en la estructura de la propiedad, de comunal a privada, según Guichard (1980, 70) hirió de muerte los principios socio-económicos de la sociedad mudéjar y abrió un abismo entre ambas comunidades, que iria paulatinamente ensanchándose.

La llegada de los pioneros cristianos coincidió con la expulsión de los mudéjares decretada por Jaime 1 . Un total de unos 100.000 fueron los expulsados, la mayor parte de tierras de realengo. Guichard $(1980,29)$ considera que la población musulmana de Cocentaina se vio fuertemente afectada por 
la orden de expulsión y que su recuperación resultaría problemática. La documentación local no deja entrever nada que confirme tal afirmación.

La presencia cristiana en sus tierras hacía que el mudéjar se sintiese invitado en su propia casa, lo que hizo que se aferrase aún más en su propio pasado como forma de liberarse de ese intrusismo. A su vez, esa actitud hacia que el cristiano mostrase cierto rechazo hacia esa cultura y en esta situación, la convivencia no resultaba nada fácil, sobre todo para aquellos que tenian una mayor conciencia del problema que veían en la emigración a Granada o Tunicia la única salida válida. Todo ello no impide que la vida cotidiana se desenvuelva en constantes contactos entre ambos grupos, que si bien estaban separados por sus creencias y por otros motivos de indole material, las relaciones sociales y económicas permitieron que nuevas actitudes fueran transmitidas por ósmosis de una a otra comunidad (Burns 1975, 11).

Las interferencias culturales eran algo conocido por la Corona y la Iglesia. La convivencia y la libertad religiosa, en que se desenvolvía el vencido, podía generar algún caso de apostasía, por lo que la Iglesia dictó una serie de medidas tendentes a restringir la convivencia entre ambas comunidades religiosas, recogidas después en las órdenes reales (Barceló 1984, 94) con el fin de desalentar a las almas débiles. De este modo se conseguía detener el problema más no solucionarlo, ya que las causas permanecían inalteradas. Las insistentes cartas, como la recibida en Cocentaina el 11 de febrero de 1269 (Baño 1980) (Gual Camarena 1949, 170), en la que se prohibía la conversión al islamismo, habla por sí sola de la facilidad del contagio.

No se conoce en Cocentaina ningún caso de apostasía en los libros de la Cort de Justicia durante el siglo XIII, si bien, son muy pocos los conservados. El primero conocido data de 1303, durante la época turbulenta del asedio de Cocentaina por los «genets» granadinos; Joan de Vilaró fue condenado a la hoguera por haberse convertido al islamismo por dinero, después de abjurar el judaísmo y hacerse cristiano, disgustando seriamente a las autoridades esta actitud libertina del reo (A. M. C. 1303, 97).

Paralelamente a esta serie de medidas tendentes a evitar la influencia religiosa mudéjar, la Iglesia y la Corona unirán sus esfuerzos con el fin de estimular a los mudéjares a convertirse a la religión cristiana, otorgando al converso la igualdad jurídica con el cristiano y en el caso de esclavitud se le reconocía la libertad (Mateu y Llopis 1952, 39-43). La conversión interesada de muchos musulmanes obligará a las autoridades eclesiásticas y civiles a la adopción de algunas medidas restrictivas (Barceló 1984, 93).

Pero esta política de atracción del elemento mudéjar, necesaria para la buena marcha del reino, no contó con la colaboración de la población, de 
tal forma que si se producian conversiones, en ningún caso eran debidas a la vida ejemplar que llevaban los cristianos (Fuster 1962, 27) (A. M. C. 1277 , 25), sino al espejuelo de las ventajas sociales que la conversión conllevaba. Por todo lo cual, los cristianos desconfiaban de aquellos que abrazaban su religión, pue sabian que ésta era por conveniencia más que por convicción, por lo que se resistían a su integración dentro del ambiente cristiano (Barceló 1984, 93). Así, en vez de procurar formar el espíritu del converso, fue objeto de discriminación y malos tratos (A. M. C. 1277, 25), quedando el néofito en una situación de desamparo por parte de sus nuevos y antiguos correligionarios. Las quejas llegarán a oidos del rey que dictará severas medidas contra todo aquél que les hiciere deshonor (Aureum opus VI, Jaime II, XL).

Dentro de este contexto de rechazo-atracción se inserta el primer contencioso conocido de la villa contestana entre ambas comunidades. En 1269, el herrero Abdurhamet (A. M. C. 1269, 35v)acuerda con Bernat Busquet que su hijo permanecerá durante tres años en casa del primero como aprendiz. Apenas había transcurrido el primer año cuando el padre decide retirar a su hijo de casa del maestro en contra de la opinión de éste. La actitud del padre, violando lo acordado, hace que el herrero recurra ante las autoridades cristianas en demanda de justicia como era preceptivo (Barceló 1984, 47). Ante las mismas le acusa de incumplimiento de contrato. El padre reconoce el haber establecido un contrato de aprendizaje con el herrero, pero alega en su favor que ningún cristiano puede estar al servicio de un musulmán, por lo que según las leyes del momento el contrato de aprendizaje era ilegal (A. C. A. $38,72)$. La alegación del padre resulta sorprendente, pues sabido era que su hijo debía de convivir con el maestro durante el período del aprendizaje.

Parece evidente que la preocupación paterna por darle un buen porvenir a su hijo aprendiendo un oficio de tanto prestigio social (Hilton 1978, 41), se anteponía a una serie de prejuicios. El padre decide retirar a su hijo del proceso de aprendizaje, no porque considere incompente al maestro, sino presumiblemente por presiones sociales. La convivencia maestro-discípulo no debía resultar del agrado de la comunidad cristiana contestana y bastaría con cualquier nimio detalle para que sus convecinos viesen en ello la influencia nefasta de su maestro en materia religiosa. El fallo de la Cort de Justicia nos ha sido vedado, pero no debió de ser del agrado del maestro, pues a tenor de un acuerdo del consejo local el 29 de septiembre de 1275 (A. M. C. 1275 , 37), Abdurhamet debió de abandonar la villa hastiado por el tratamiento discriminatorio, pero reconociendo el consejo el inmejorable papel de sus servicios a la comunidad le concede las mismas franquicias fiscales que gozan los cristianos contestanos si se establecia de nuevo en la villa, también se le 
reconoce la posibilidad de tener hasta tres discípulos en su taller, siempre y cuando sean musulmanes. La oferta habla por si sola y nos hace ver la aparente libertad de movimiento de los mudéjares antes de 1275 y de la importancia económico-social del mudéjar cualificado (A. M. C. 1275, 37v) (Gual Camarena 1949, 171).

La vida fluía en Cocentaina dentro de una perfecta calma, que sólo se veía alterada por algún que otro acontecimiento como el narrado. La tolerancia hacia el vencido era la tónica general, pero hay que matizar que el mudéjar pagaba por ello un alto precio (Burns 1982, 397). La expansión económica y social de la población contestana se hará a costa de la minoría mudéjar. Los cristianos lentamente les irán usurpando sus menguados bienes, como si se pretendiese ensayar con ellos hasta donde llega su capacidad de resistencia (A. M. C. 1269, 40).

La presentación de los hechos de esta forma podría darnos una interpretación deformada de la realidad. Cocentaina está formada por dos demarcaciones urbanas bien claras: el arrabal y la «vila» (Navarro Reig 1985). La primera poblada por mudéjares considerados social y en otros aspectos inferiores; en la segunda, los cristianos, antítesis de la anterior. Los dos se complementan y se necesitan, son capaces de vivir en armonía y de enfrentarse, si llega el momento, pero, en el caso de producirse, los culpables de tales acontecimientos serán siempre los del arrabal. Esta situación tan peculiar no desaparecerá, ni con la conversión, ni con la expulsión, sino que es algo tan propio de esta villa que ha perdurado, aunque mitigado, hasta la actualidad.

Estas dos demarcaciones: social, psicológica y urbanísticamente diferentes, se relacionan mutuamente, pero dentro de unas condiciones de orden jerárquico.

Los cristianos aprovechan la experiencia mudéjar en el cultivo de la huerta, sus autoridades son consultadas e incluso llegan a pronunciarse jurídicamente en los problemas relacionados con el sistema de aparcería, incluso siendo uno de los litigantes cristiano; sus topónimos darán nombre a las partidas rurales; costumbres y vocablos serán asimilados de forma más o menos sensible; procuradores mudéjares representarán a cristianos y viceversa; compartirán el mismo rincón en la taberna, el mismo vino e incluso las mismas mujeres públicas, pese a lo que digan las disposiciones reales; los niños confraternizarán en el juego, sin ningún tipo de prejuicios, etc. (A. M. C. 1275, 4; 1277, 36, Burns 1981, 254).

Los mudéjares acuden en demanda de justicia ante la Cort, a pesar de tener su propio alcadí que entiende en los asuntos internos de la comunidad. 
La mayor parte de los litigios incoados ante la Cort de Justicia corresponden a mudéjares residentes en diferentes localidades. Intentar dar una justificación de esta actitud resulta problemática ya que oficialmente disfrutaban los mudéjares de un zalmedina, Abduluhabeb Albini, nombrado por la corona el 14 de julio de 1275 con jurisdicción desde Cocentaina sobre toda la Montaña (A. C. A. 20, 270v). Las únicas razones que podemos aducir es que o bien dicho cargo estuvo poco tiempo en ejercicio, siendo posteriormente suprimida dicha institución, o bien el justicia cristiano disfrutaba dentro del mundo mudéjar de una mayor autoridad. La Cort, por su parte, en ningún momento desatendió dichas demandas, sino todo lo contrario, dados los beneficios económicos que conllevaba, pero en las causas criminales fueron obligados a recurir ante el baile (A. M. C. 1275, 4; 1294, 4; A. C. A. 19, 18; 13, 236).

El estallido de la segunda revuelta mudéjar va a acelerar el enfrentamiento entre las dos comunidaes. La coincidencia del movimiento con una crisis social en el seno de la comunidad cristiana, la aparición del bandolerismo y los excesos de las mesnadas concejiles y reales, van a poner al rojo vivo la convivencia entre cristianos y mudéjares.

Una fuerte sensación de inseguridad invadió a los cristianos, que temerosos de las «tornas» mudéjares abandonaron sus hogares en busca de lugares más seguros pese a las reiteradas amenazas de confiscación de bienes y destrucción de sus casas (A. M. C. 1276, 73).

Interesante y muy esclarecedor de la realidad vivida en esos momentos es el bando Arnau Escrivá procurador general y baile de Valencia, ordenó publicar el 15 de julio de 1275 en su visita de esta villa y que transcribimos al castellano en las líneas siguientes (A. M. C. 1275, 37v):

1. Ordena a los habitantes de Cocentaina mantener y defender a los musulmanes del arrabal y a todo su término bajo penas corporales y económicas.

2. Se prohibe hacer comentarios en público sobre la guerra bajo pena de prisión.

3. ${ }^{\circ}$ Se prohibe a cristianos y musulmanes circular fuera de los caminos reales bajo pena de prisión.

$44^{\circ}$ Se permite a todos los moradores que puedan disponer del pan suficiente para sí y su familia, no en mayor cantidad, bajo pena de prisión y confiscación. 
$5 .^{\circ}$ Se recuerda a los vecinos la obligación de residir en la villa y en su defecto sea inscrito en los libros de la Cort.

6. ${ }^{\circ}$ Se insta a los «prohomens» de Cocentaina para que cuiden y mantengan a los musulmanes que vengan de Murcia y de Granada.

Si el miedo cristiano parece ser grande, no lo es menor el mudéjar, sospechosos de connivencia con los rebeldes. Su ganado sugre el expolio por los cristianos, pese a las reiteradas órdenes reales de protección y defensa de los mudéjares, el rey y sus oficiales se ven desbordados (A. M. C. 1277, 25).

No son sólo los bienes materiales los que están en peligro durante la revuelta, sino su propia integridad física. El caos reinante estimula a que grupos de desaprensivos o resentidos, residentes o foráneos, de forma más o menos improvisada, aprovechen la oportunidad para realizar excelentes negocios con el rapto de «moros de pau», es decir, mudéjares no sumados a los rebeldes, situados bajo la especial protección de la corona; y el asalto a sus aljamas, donde cometían todo tipo de excesos. Muchas de estas acciones no deben incluirse en los episodios de la guerra, pues el motor de estos acontecimientos lo constituye el problema social de enfrentamiento de los diferentes grupos cristianos surgidos con la repoblación, en donde los mudéjares sirven de válvula de escape para la tensión concentrada en las masas populares (A. M. C. 1276, 65 y 76).

La actitud de estas bandas hacia los pacíficos mudéjares no hacía más que complicar la situación, pues los más remisos se veían, de esta forma, alentados a tomar partido en favor de sus correligionarios de una forma más o menos encubierta: tráfico de vituallas, paso de información, cobertura para los rebeldes, etc. Todo ésto era bien conocido por las autoridades y por ello se tomaron las medidas oportunas. La documentación local rara vez alude al tema de la revuelta y si lo hace, emplea una forma indirecta (A. M. C. $1275,37 v)$.

Pese a las severas medidas reales para proteger a los mudéjares leales, éstos no van a verse libres de las acciones cristianas. La más célebre fue la de Berenguer Meler y Miguel de Valencia condenados, rspectivamente, a la pena capital y a la amputación de un pie, por su participación en el secuestro de un mudéjar de Bélgida, por el justicia de Cocentaina estando presente el propio Roger de Lauria (A. M. C. 1277, 27). Consecuencias mènos trágicas para sus protagonistas tuvo el asalto al arrabal contestano por los almocatenes castellanos que desde Murcia acudieron en ayuda del rey aragonés con el fin de reprimir la revuelta. Según el relato de un testigo presencial, éstos 
acordaron en la era situada extramuros de la villa asediar el arrabal y llevarse a sus tierras cuantos bienes y mudéjares pudiesen. El hecho, conodido por el rey, fue notificado a las autoridades murcianas con el fin de que reparasen el daño causado y se castigase a los infractores (A. M. C. 1277, 26v-27).

Aparte de estas acciones existen otras muchas de robos en la aljama y del apresamiento o rapto de mudéjares llevadas a cabo por los propios vecinos de la villa. En algunos casos el castigo por tales hecho era atroz, pero en la mayoría de los casos se limitaban a la confiscación de los bienes del raptor, aunque si se contaba con medios económicos y amigos influyentes se podía lograr fácilmente el perdón oficial (A. M. C. 1275, 55v; 1277, 24; 1278 , 50) (A. C. A. 23, 68v). Los peor tratados por la justicia fueron las bandas armadas que buscaban en sus acciones sólo el lucro personal y no la restauración de la autoridad regia.

La respuesta mudéjar a tantos desmanes no se hizo esperar. Al igual que los cristianos, formaron sus bandas armadas con el fin de capturar cristianos y venderlos como esclavos en tierras musulmanas. La identidad de intereses hace que unos y otros unan sus esfuerzos, en determinadas circunstancias, $\sin$ importarles las diferencias que les separaban. Los dos textos siguientes, que reproducimos en versión castellana, son lo suficientemente explícitos para comprender la realidad de la situación: "Guillem de Belcaire declara que al principio de la guerra se fue con Bernat de Limiñana, Bernat Savall, Pedro Pérez y Rodrigo, prendieron a cinco mudéjares, los metieron en una barca y los llevaron a Oliva, desde donde Limiñana y Savall los llevaron, junto con otros siete a lbiza. Pedro Pérez y Rodrigo, estando en Denia, oyeron decir que Limiñana estaba reclamado por la justicia, tuvieron miedo y se fueron, pasando tres semanas con Alcayd Mohamat, luego quince días en Pego, de aqui a Biar con Mohamat Alcbach y veinte mudéjares más, que tenian en una alquería de Penáguila a quince cristianos cautivos, matando a dos de ellos. De aqui, junto a un mudéjar, se fueron al castillo de Palma» (A. M. C. 1277 , 43). "Amet Aben Hibil confiesa que él, Noge, Monço, Mohamat Aben Hibil, su hermano Axir y Amet Al Rafa salieron del arrabal de Cocentaina con la idea de coger algún cristiano para llevarlo a la zona rebelde y cuando estuvieron en el higueral de Martín de Azagra, vieron dos cristianos, intentaron cogerlos, pero se les escaparon. De aquí se fueron a Planes y luego a Alicante, finalmente tomaron el acuerdo de ir a saltear al puerto de Albaida junto con otros seis compañeros" (A. M. C. 1277, 33v).

Mientras todos estos acontecimientos ocurrian, la revuelta iba debilitándose y la corona daba todo tipo de facilidades a los vecinos para realizar cabalgadas contra los que perseveraban en su rebeldía. Se determina la zona 
apta para el apresamiento de cautivos, se renuncia al quinto real, se liberaliza su tráfico, etc. (A. M. C. 1277, 18).

Al final tan sólo queda Montesa, con su caida los mudéjares entierran todas sus esperanzas. Ahora, desorientados, frustrados y faltos de confianza en sí mismos no les queda más que vegetar.

Un proceso curioso ilustra una vez más el sentimiento del pueblo vencido. El 20 de julio de 1277 Mohamet Alhoemi, hallándose en la taberna en claro estado de embriaguez, empezó a insultar al rey Pedro, llamándole traidor e indigno de ocupar el trono. Alarmadas las autoridades, es apresado y llevado ante la Cort. Alli declara que el rey había prometido a los mudéjares no talar sus campos de Montesa y poner en libertad a los prisioneros capturados durante la guerra, todo ello a cambio de un donativo de 14.000 sueldos. Cobrada dicha cantidad, no cumplió ni una cosa ni otra, pues su hermano, que se halla entre los prisioneros, aún está retenido en Valencia (A. M. C. $1277,23 v)$.

Mahomet ha tenido que recurir al vino para liberarse de la tremenda presión contenida en su interior. Sabe que las circunstancias han cambiado y que de un respeto aparente se está pasando a una creciente intransigencia. Ya no puede confiar en nadie, ni en la justicia cristiana, ni en la palabra real. No le queda más solución que aceptar su destino o emigrar. Algunos optarán por echarse al monte, sembrando el terror entre los viandantes, aunque su final está también cercano (A. M. C. 1294, 6v). La mayoria permanecerá en sus hogares y buscará, como Phameni Auxaumni (A. M. C. 1294, 40), la protección de Roger de Lauria o de algún otro personaje influyente que la defienda contra ofensas y embargos y le garantice la posibilidad de vivir tranquilamente en sus tierras. Al convertirse Cocentaina en señorío de Roger de Lauria, los mudéjares se integraron dentro de la economía señorial (Reglá 1968, 47) (Ciscar 1977, 107 y 137).

Paulatinamente los mudéjares han ido perdiendo sus recursos económicos, su condición jurídica y su valoración social, convirtiéndose en vasallos de segunda. En el aspecto religioso, su libertad se ve constantemente mermada, y en el campo cultural, su postración es abismal por la pérdida de sus elementos más cualificados emigrados paulatinamente a Granada. Ahora son meros instrumentos de trabajo cuya única ambición es el poder subsistir materialmente (Gil Olcina 1979, 24) (Martínez Ferrando 1963, 24) (Torres Fontes 1961, 73-75). En ello no sólo influyeron las revueltas, sino que, como afirma Burns (1981, 263, 275 y 299), serán las pasiones del pueblo y del clero, sobre todo el regular, quienes lo exigirán. A todo ésto sólo faltará añadir el proceso de señorialización que está sufriendo el reino. 


\section{STRUCTURA DE LA SOCIEDAD MUDÉJAR}

La sociedad contestana, al igual que en otras partes del Reino de Valencia, estuvo formada por la adición de tres grupos religiosos: musulmán, cristiano y judío. Con toda seguridad, en el momento de su conquista por Jaime I estuvo formada exclusivamente por musulmanes, pues la minoria mozárabe debió de haber desaparecido de estas tieras bastantes décadas atrás (Epalza y Llobregat 1982, 24-31).

Con la llegada de los primeros cristianos repobladores se va a engendrar una nueva estructura social en la que «la minoría conquistadora trató de prescindir de la superioridad numérica mudéjar. En torno a sí creó la ilusión de su única presencia... Lo consiguió de la forma colonial tradicional: creando una superestructura urbana y señorial, dotando a su contexto inmediato de cualquier detalle que pudiera transportar a sus tierras de origen y tratando a la población autóctona como una casta inferior que habia que tolerar en ghettos cerradosm. (Burns 1982, 666)

Junto a estos dos grupos hará acto de presencia un tercero, el judio, numéricamente poco importante, pero de un enorme influencia económica, sirviendo, al mismo tiempo, para romper esa rígida bipolarización social (Baer 1981, 157-8).

De los tres grupos sociales el que concretamente nos interesa en este caso es el mudéjar que constituía el elemento humano originario. Vivian diseminados por los campos contestanos en pequeños núcleos rurales, llamados alquerias, cuyos nombres, en ciertos casos, han resistido el paso de los años y en la actualidad designan alguna partida rural. Junto a esta población diseminada destacaba Cocentaina, núcleo urbano emplazado en la falda de su castillo. La reconquista cristiana va a incidir negativamente sobre ellos a todos los niveles y si no desaparecieron antes, fue, gracias al interés de la nobleza por conservarlos.

Las antiguas comunidades rurales asentadas en las alquerías pasaron a constituir el interesante grupo de los exáricos (que trataremos posteriormente), los arrendatarios o los jornaleros que explotaban los mismos campos que antaño, pero en beneficio de la clase cristiana ahora dominante. En el núcleo urbano de Cocentaina se verán reducidos a vivir en su arrabal, dedicándose, uno a los quehaceres agrarios, otros, más agraciados, a oficios artesanales: herrero, tintorero, albañil, etc.

Estos grupos, sin líderes políticos ni religiosos que les hiciesen tomar conciencia de sí mismos, iban sumiéndose en un profundo letargo cultural, reli- 
gioso, político, etc., transformándose en auténticas máquinas productivas para satisfacer las exigencias de sus señores, de tal forma que cuando pretenden autodefinirse, tendrán que hacerlo en contradicción a lo que representa el cristiano.

Cualquier estimación sobre el volumen de población mudéjar resulta, hoy por hoy, imposible de cuantificar (Burns 1982, 665) (Barceló 1984, 67). La carencia de una documentación oficial sobre los impuestos así como el hecho de que sus asuntos judiciales internos sean llevados por su alcadí dificulta el confeccionar cualquier estimación demográfica como la que hemos llevado a cabo para la población cristiana contestana del siglo XIII. Ni siquiera es posible establecer una proporcionalidad con la cristiana.

En los libros judiciales del Archivo Municipal de Cocentaina se recogen demandas incoadas entre cristianos y mudéjares. Su estudio, aunque no ha permitido acercarnos a su realidad demográfica, sí que, al menos, ha servido para aproximarnos a hacer una valoración de su estructura socio-económica.

En la sociedad mudéjar contestana, al igual que en otros lugares del reino, destaca una minoría selecta que encarna la representación política, económica y social de su comunidad al controlar en sus manos todos o la mayor parte de los recursos económicos: monetarios y territoriales, consentidos por los cristianos en función de su convivencia o de los términos de las capitulaciones (Barceló, 53-54). Esta hegemonía les hará acreedores del desempeño de los altos cargos políticos de su aljama. Como personalidades conocidas en el siglo XIII tenemos:

Ali Huarathateb que qbtiene en pública subasta las regalias de la alhóndiga y del mercado en 1269 por más de 1.000 sueldos. En 1275 alquila por 60 sueldos un huerto de Ximén Pérez de Oriz. Como persona pública desempeñó el cargo de alamín desde 1269, posiblemente ya antes, permaneciendo en su puesto al menos hasta 1275, incluso es posible que hasta 1294 (A. M. C. $1269,1 \mathrm{v} ; 1275,30 ; 1294,17 \mathrm{v}$ ).

Abdulhuaheb que en 1269 adquiere el almudín por 190 sueldos. El 14 de julio de 1275 Jaime I le nombre zalmedina del arrabal de Cocentaina. Ese mismo año compró a Ponç Guillem las rentas de las regalías que había obtenido en la subasta, 100 sueldos por encima del precio de adjudicación. También tuvo en arriendo el peaje por 480 sueldos que por gracia especial, dados sus desvelos por mejorarlo, se vieron reducidos a su mitad (A. M. C. 1275, 8v) (A. C. A. 20, 270v).

Amet Pascuyal compró a Martín Pérez de Gracia una vasta extensión de tierras en Penáguila por 820 sueldos en 1294. También durante ese mismo 
año aparece como acreedor de muchas familias tanto cristianas como mudéjares (A. M. C. 1294, 47v).

El Alfaquí Mosse, aparece durante 1269 envuelto en varias demandas, aunque ello no implique su residencia obligatoria en la villa (A. M. C. 1269 , $20 \mathrm{v}$ y $24 \mathrm{v})$.

La "clase media" estuvo formada por profesionales autónomos que viven principalmente de la renta de su trabajo. Destaca el grupo de los artesanos libres, como Mohamat el Corretger, Abdurhamet el herrero, Alf el tintorero, etc. A estos podríamos añadir un pequeño grupo rural formado por la clase acomodada propietaria de ganado, como Aben Abençala; de tierras en la zona reservada a ellos o que arrienda propiedades cristianis para su puesta en explotación, como Mohamat Aben Ornagra (A. M. C. 1275, 9v y 50).

En la clase inferior se integraba la mayor parte de la población mudéjar por carecer de recursos económicos o de una preparación técnica profesional. Pertenecerán a ella el grupo de los asalariados agrarios que trabajan las tierras de los propietarios cristianos, como Mirdacix, o realizan trabajos urbanos por cuenta de otros, como Abnaxay (A. M. C. 1269, 47; 1275, 53). A continuación vendrían los exáricos, formado, presumiblemente, por una importante masa de población y que dada su singularidad dedicaremos un apartado espacial para analizar sus peculiaridades. Su estrato superior pudo, muy bien, compararse a la mencionada "clase media" y cuyas capas más bajas entroncan con los mudéjares esclavos. Los exáricos trabajaban las tierras de los propietarios cristianos en unas condiciones que dependerán de la voluntad de sus dueños y de la coyuntura del momento.

El peldaño más bajo de la escala social lo ocupan los esclavos. Su número debió de ser muy importante en el Reino de Valencia, en estos momentos, habida cuenta de los acontecimientos que siguieron a su conquista. Varlinden $(1934,283-448 ; 1935,361-424)$ que se ha ocupado del problema calcula para Cataluña un total de unos 10.000 , mientras que en Valencia su número debió de ser muy superior.

La mayor parte de los esclavos de estas tierras son de origen musulmán, pero junto a éstos compitieron otros de origen cristiano y judio. En Cocentaina sólo tenemos noticias de la presencia de esclavos musulmanes, aunque en las tierras montañosas limítrofes existió, durante la revuelta, un mercado de esclavos cristianos conectado con el gran mercado de Granada (Sanchís Llorens 1972, 35).

La legislación foral y la Iglesia se hicieron eco del problema y dictaron una serie de medidas con el fin de mejorar la situación del esclavo, defender- 
les contra los abusos y malos tratos de sus dueños. La Iglesia se preocupó, especialmente, por las relaciones ilícitas entre el señor y sus esclavas, y sobre la suerte de la posible descendencia, primando, en todos los casos, el condicionamiento religioso, postura que se ve perfectamente recogida en los fueros.

Las revueltas mudéjares de 1248 a 1276 van a constituir importantes manantiales de suministro de esclavos. La corona delimitará, a modo de cotos de caza, aquellas zonas donde se permita la captura de musulmanes declarándoles «moros catius", es decir, musulmanes rebeldes susceptibles de poder se hechos cautivos en beneficio de su apresador, reanunciando la corona a su quinto real (A. M. C. 1275, 29 y 65v). Por el contrario, estarán sujetos a la especial protección del monarca (Burns 1981, doc. 25) los «moros de pau», es decir, aquellos que se mantuvieron fieles al monarca aragonés, amenazando con severas sanciones a todo aquél que les cause algún daño o privación de libertad (A. M. C. 1276, 76; 1277, 43). De hecho las autoridades no fueron con remilgos en este asunto y en Cocentaina conocemos, como ya hemos apuntado más arriba, la primera sentencia a la pena capital y amputación de miembro a dos integrantes de una banda armada cristiana que en 1277 había secuestrado a un "moro de pau» en Bélgida (A. M. C. 1275, 24). Tan cruel sentencia no amilanó a las otras partidas, cristianas o cristianos, que se enseñoreaban por la zona.

El problema radicaba también en distinguir entre "moro catiu o de pau», cosa que no resultaba tan fácil. Por ello se facultó al baile general para que entendiese en estos puntos (Piles Ros 1970) (Roca Traver 1951, 188). «La primera condición necesaria para que una persona fuese declarada esclava era de que su cautiverio fuese declarado legal, o sea, que sea "aprocehit en bona guerra"» (Sanchís Llorens 1972, 18).

Por tanto, antes de proceder a la venta de un cautivo, el baile debía interrogarle para determinar si se le podía considerar esclavo, pero por desgracia todo aquél que caía dentro de las redes de la esclavitud, contaba con muy pocas posibilidades para poder escapar de ella por este conducto, pues era la palabra del esclavo contra la de su dueño. Una vez declarados, una forma de escapar de dicha condición era obtener licencia del baile para poder pedir limosna (acaptar) entre los musulmanes con el fin de pagar el rescate (Barceló 1984, 87).

Durante la revuelta, todo mudéjar que fuese encontrado portando armas, al ser reducido pasaba a propiedad del vencedor, que podía disponer libremente de él. Tras comunicarlo a las autoridades, estaba facultado para po- 
derlo vender, pignorar, ceder, dejar en herencia, etc. (A. M. C. 1269, 4v; 1275 , $32 v$ y $67 \mathrm{v} ; 1277,15 ; 1278,40$ ) (A. C. A. 19, 16v). Pero junto a estas capturas legales, proliferaron para raptar al mudéjar solitario, que permanecía pacíficamente trabajando su tierra o cuidando el ganado, siendo rápidamente sacado del lugar y trasladado a Valencia, Ibiza, Castilla o cualquier otro lugar para ser vendido como esclavo (A. M. C. $1277,24,43$ y 91).

Terminada la guerra, la fuente básica de tan preciado botín entró en una profunda agonía, con lo que el número de esclavos mudéjares fue lentamente disminuyendo. Unos gracias al rescate otros por huir de la residencia de sus propietarios, hastiados de sufrir vejaciones y malos tratos (Sanchís Llorens 1972,24$)$. El esclavo fugitivo se llevaba de casa de sus señores cuanto podía, por lo que a su condición de huido unía la de ladrón. Por ello se veía obligado a caminar campo a través lejos de los lugares más frecuentados, para evitar el ser descubierto, soñando con llegar a tierras granadinas donde podria encontrar su ansiada libertad. Las penalidades y los riesgos del viaje eran innumerables, pero la recompensa final bien valia el correrlos.

Los que no conseguian alcanzar la ansiada meta por ser descubiertos, eran encarcelados por orden del justicia, para luego proceder a su identificación y devolución a su dueño. Si resultaba desconocido, era encomendado a un «prohom" hasta que alguien lo reclamase. Pasado un tiempo prudencial sin haberse producido la reclamación, pasará a propiedad real y podrá ser vendido de nuevo en pública subasta (A. M. C. 1294, 5 y 5v) (Aureum Opus $X$ Pedro I, XXXV).

Las ventajas económicas que obtenían sus aprehensores derivadas del derecho a una parte del producto de venta del cautivo, hará que se organice todo un sistema encaminado a perseguir insistentemente a los esclavos fugitivos y desconfiar de aquellos que viajan fuera de los caminos reales, de ahí que se les conozca a los esclavos huidos como «descaminats" (Sanchís Llorens 1972, 25).

\section{A EXARIQUIA COMO SISTEMA DE EXPLOTACIÓN AGROPECUARIA}

La reconquista de las tierras levantinas influyó negativamente no sólo en la población musulmana sino también en la organización de su sistema económico. El campo se hizo eco de la nueva situación creada que suponen unas transformaciones que determinan toda una serie de sistemas de explotación.

El esfuerzo realizado para su conquista se justificaba sólo si se lograba amortizar los dispendios económicos y humanos realizados. Las disponibili- 
dades de tierras en todo el sur valenciano eran importantes, mientras que el número de colonos asentados fue durante las primeras décadas muy escaso, a pesar del interés que despertó a todos los niveles. Estos acontecimientos van a influir decididamente a la hora de organizar la explotación del suelo.

La abundancia de tierras permitía que, en principio, tanto los vencedores como los vencidos disfrutasen de la tenencia de propiedades e incluso que tengan acceso al mercado de la tierra, pero el problema no radicaba en su posesión, sino en torno a la posibilidad de explotación.

Pasados los primeros momentos, los cristianos fueron acumulando, cada vez, mayor cantidad de tierras en detrimento de los mudéjares, que ven perder lentamente sus propiedades; salvo algún personaje acomodado, en general, la mayoría pasa a engrosar el grupo de los agriculores sin tierras (A. M. C. $1294,47 v)$.

En estas circunstancias los cristianos van a necesitar de los servicios de la población mudéjar, y de su trabajo va a depender, en buena medida, el bienestar de la comunidad cristiana. La estructuración de la producción agraria sobre la mano de obra mudéjar va a convertir a los vencidos en máquinas al servicio de los propietarios cristianos. El proceso, estimulado por la crisis económica y por la señorialización del país, va a ser lento, pero irreversible. Las condiciones primitivas (Renouvard 1962, 231-264) (Ciscar 1977, 107) contenidas en las cartas-puebla y en otros documentos jurídicos inician a partir de ahora un incontenible proceso de degradación que de una forma insensible va alejando la costumbre cotidiana de su punto de partida legal.

Los nuevos vecinos de Cocentaina procedían de lugares diversos y con una experiencia agraria no siempre válida en estas nuevas tierras. Las únicas concesiones de huertas se darán en Cocentaina (Ferrer Navarro 1982, 9-27) (Barceló 1984, 80). Su explotación requerirá de una experiencia que no siempre disfrutarán los nuevos propietarios, ello permite al campesino mudéjar continuar al frente de la explotación aportando sus modos de trabajo y sus sistemas jurídicos de explotación de la tierra (Furió 1982, 47 y 67) (Leví-Provençal 1965, 151).

Procedemos ahora a señalar los diversos tipos de regímenes de explotación deteniéndonos, especialmente, en la exariquía.

El régimen de explotación puede adoptar dos modalidades:

El directo, empleado preferentemente por el pequeño propietario.

El indirecto, propio de los grandes y medianos propietarios. Este régimen adopta las siguientes formas: 
A censo. Tiene como finalidad obtener una rentabilidad estable y segura que permita la dotación económica suficiente para la creación, generalmente, de obras pias y de previsión familiar (García y Sanz 1961, 286). El receptor del censal tiene la facultad de poder transmitirlo en herencia, venderlo, cederlo, subarrendarlo, etc., recibiendo el señor eminente el luismo y la fadiga. Su sentencia no sólo obliga al pago de las anualidades, sino que todos los gastos de mantenimiento y conservación van a su cargo, pudiendo en su caso ser demandado por el propietario si no presta el suficiente celo (A. M. C. $1275,41)$.

Por arrendamiento. En este caso el propietario se desentiende de la explotación durante un periodo reducido de años. El arrendatario entrega al propietario una cantidad fija en metálico y/o especies en una o en varias veces, generalmente, por San Juan o San Miguel, debiendo comprometerse a mantener en condiciones óptimas la explotación, bajo su responsabilidad. Igualmente está facultado para poderla subarrendar por un periodo no superior al tiempo de arrendamiento (A. M. C. 1275, 16 v y 52) (Gisbert 1950, 305-330). Este sistema fue bastante utilizado, arrendándose bajo tipo de propiedades, tanto a cristianos como a mudéjares (Barceló 1984, 83) (A. M. C. 1275, 16v y 29v).

Por asalariados. El propietario que, por las circunstancias que fuesen, no pueda ocuparse él de la explotación de sus tierras recurre a la contratación de mano de obra, cristiana o mudéjar, que recibirá por su trabajo una cantidad en metálico o en especies en concepto de salario (A. M. C. 1269, 47; 1305,118 ) (Furio 1982, 71). En la mayoría de los casos, el asalariado no cons. tituye una mano de obra estable, vinculada permanentemente a un mismo patrón, sino que está condicionada a la realización de una labor agricola determinada. Se le contrata para cavar, poder, arar, etc. la propiedad. Se le exige un trabajo bien hecho, según la costumbre de los «bon llaurador» (A. M. C. $1275,47 ; 1277,22 ; 1290, \mathrm{~s} / \mathrm{f})$. Este tipo de contratos pueden acordarse por una o varias temporadas, presentándose un serio problema sobre suvalidez si entretanto cambia la titularidad en la propiedad de la tierra. En esos casos el nuevo dueño no se siente obligado por los acuerdos firmados por su antecesor (A. M. C. 1275, 23).

Aparcería o exariquia. El estudio de este régimen de explotación presenta una mayor complejidad. La razón se debe, posiblemente, a que mientras éstos son utilizados hasta el día de hoy o como el censo que representa una modalidad bien conocida, el sistema de aparceria constituye una aportación de las minorías mudéjares de sus formas tradicionales de explotación agraria. 
Por todo ésto, a la hora de precisar el carácter específico de la aparcería y de su relación con la figura del exárico, encontramos serias dificultades que nos obligan a salirnos del marco estricto de la Cocentaina cristiana del siglo XIII y retroceder en el tiempo para encontrar sus raíces en la dominación musulmana.

Leví-Provençal $(1965,151)$ afirma que en las fincas de propiedad grande y mediana, el colonato era corriente en el conjunto de los territorios hispanos de Al-Andalus.

Estos colonos recibían varias denominaciones: «particeps" o aparecero, «munăsit» o mediero, y «sharik» o asociado, de donde procede la forma latinizada "exaricus» que aparece en ciertos documentos aragoneses del siglo XII $y$ el «exaric» o «xaric» de los valencianos del XIII.

Con la conquista cristiana de las tierras del Ebro y del sur del reino de Valencia, en donde la presencia mudéjar es importantísima, el sistema de colonato de origen islámico no desaparecerá, sino todo lo contrario. Ante la necesidad de recurrir a la mano de obra mudéjar, y por el hecho de coexistir propiedades en manos cristianas junto a otras mudéjares, respetadas a causa de las capitulaciones, pervivirán los viejos contratos de aparcería musulmanes que serán aceptados como cosa propia por los propietarios cristianos, sufriendo, no obstante, las consiguientes transformaciones, consecuencia normal del uso de cualquier institución.

El «munāsif» o mediero es una forma habitual de explotación agraria en la Cocentaina medieval e incluso actual. El propietario aporta la tierra y el agricultor las manos, pagado los gastos habidos, se reparte el excedente a partes iguales (A. M. C. 1275, 35v; 1314, 107v) (Guichard 1980, 72).

Para el «sharik», volvamos a Leví-Provençal, quien analiza los diferentes contratos-tipo de este modo de asociación.

Distingue tres modalidades:

Musara'a: colonato relativo a los cultivos de secano.

Musăqat: colonato especialmente aplicado a cultivos de regadío.

Mugarasa: colonato que afecta, sobre todo, a la arboricultura.

De estos tres nos llaman la atención especialmente los dos primeros.

En el «musara'a» - dice Leví-Provençal- «el propietario de la tierra y el colono contratante aportan cada uno, por un periodo de varios años, por ejem- 
plo, una cantidad igual de semillas: trigo, cebada, centeno... Uno y otro proceden a mezclar cada una de esas clases de grano y el colono se compromete a labrar y sembrar los campos que toma en aparceria, a segar la cosecha obtenida, a trillarla y luego a repartirla a medias con el dueño del campo cargando a su costa todos los gastos hechos, tales como compra de bestiar de labor o ajuste de obreros agrícolas. Cláusulas especiales prevén, a veces, la obligatoria entrega al propietario por el colono de carneros o corderos cebados en cada una de las dos fiestas crónicas musulmanas y en el dia de primero de años (pág. 151) (Cf. A. M. C. 1314, 71).

No todos los contratos siguen al pie de la letra el contenido de este contrato-tipo. Algunos rebajan la parte correspondiente al colono hasta 1/4, mientras otros resultan espléndidamente ventajosos al reconocerles el derecho a los $3 / 4$ (Pla 1982, 119-138).

Estos contratos de aparcería tienen carácter privado por lo que sólo obran en poder de los interesados y en los libros del notario que los extendió por lo que no resulta fácil encontrar constancia escrita de ellos libros de la Cort de Justicia de los archivos locales. La suerte ha querido que uno de ellos haya llegado hasta nosotros a raíz de la incoacción de un proceso entre propietario y colono, lo que hizo necesario el registro en el libro procesal de dicho contrato. El documento reza así:

«Hoc est traslatum bene et fideliter sumptum a quandam instrumento in papiro scripto, cuius series talis est: Avinieran se(sic) Ali Allobadi e Ramon de Canet sobre la lavor de la terra que ha en I.Alcudia, alcharia de Cocentayna, herma o poplata, regan e secan ab arbres e meyns d'arbres e que sia aço per meytat e que sia a la meytat d'En Ramon de Canet, e que meta la meytat en la sement, e qu'es pac lo deume e la primicia de comun, e entra a laurar mijant lo mes d'octubre primer d'aquel calendari, e que prenga I primer an lo terç del oli, e d'alli anant la meytat e fo la postura a VI, ans del calendari d'aquesta carta, e can(sic)ixcha que lex les olives e que prenga la lavor dels berbeytos, e que a'N Ramon no faça neguna mision en les olives, e que laure axi con sia bon, e que prenga del laurador avant dit en tots ans $V$ sous e III, gallines. Foren testimonis d'aço qu'em la primer rahbe de l'an de (ilegible), e que meta Ramon de Canet la meytat en les alfaceras e en las esponas, e que laure Allobadi ab un parell». Concluye con el nombre de tres testigos cristianos y tres mudéjares (A. M. C. 1275, 14).

El documento no precisa comentario, su relación con el contrato «musara'a” parece clara, más aún si no perdemos el hilo del proceso judicial. 
La demanda presentada ante el justicia cristiano por Alí contra Ramón de Canet va seguida de otra efectuada por éste contra aquél por impago de las rentas de los higos. El justicia, ignorante en este tipo de contratos, echó mano de la mayor experiencia del alcadí musulmán, transfiriéndole el proceso para que según la «çunna de moros» administrase justicia. El dato creemos que es sintomático sobre la influencia islámica de este contrato (A. M. C. $1275,22 v$ y $26 v)$.

El proceso va a ser rico en aportaciones, en cierto momento parece querer descubrirnos el segundo de los contratos-tipo, es decir, el de «musãqat».

Éste se utiliza para la explotación de tierras de regadio en donde el colono explota la huerta a cambio de un tercio de la cosecha. Desgraciadamente no disponemos de ningún documento como el anterior, pero durante el largo proceso entre Alí y Ramón, un hecho llamó nuestra atención: entre los testigos presentados por Ramón de Canet había uno que figura como «moçaquis» suyo. Hechas las pertinentes averiguaciones, podriamos interpretarlo como acequiero o aparcero de Ramón de Canet ocupado de sus tierras de regadío (A. M. C. 1275, 4v y 13v. Agradecemos al Sr. Guichard sus informaciones sobre el significado de esta palabra).

Visto todo este complejo mundo creemos conveniente el abordar el problema del término «exárico». Esta palabra aparece primero en el Ebro y luego en Valencia, sobre todo al sur del Júcar. La razón de que muchos repobladores sean oriundos de aquel lugar ha inducido a muchos historiadores a asociarlos o a creer que es una modalidad importada de Aragón.

Sabemos que «exárico» ("xaric» o "xarich» si se prefiere la terminología local) es de origen árabe y representa a un agricultor que establece un contrato con un terrateniente, sin especificarse qué clase de tierra explota (Burns 1977, 102-4; 1981, 254).

Hinojosa (1904, 523-531) que ha estudiado el problema considera que durante la Edad Media el término presenta dos aceptaciones:

- Primitiva y más lata, que significa aparcero o arrendatario libre, obligado al pago de una renta proporcional a los frutos de la cosecha.

- Derivada y más estricta, designa al adscrito a la gleba, obligado también al pago al señor de un canon en especie y que no debe ser confundido con el esclavo de origen árabe, aunque podría ser objeto de compra-venta y accedía a esta situación por nacimiento.

Contra esta afirmación de adscripción a la gleba (Aracil 1983,80-1) han levantado su voz historiadores como García de Valdeavellano $(1973,354)$ que 
reconoce que, en algunos lugares, se ha hecho pero de una forma ilegal. González Palencia $(1945,83)$ corrobora esta afirmación, pero otros historiadores prefieren militar en el partido de Hinojosa, así Julio Valdeón (Historia de España de Tuñón de Lara IV 1982, 267), García de Cortázar (1975, 272 y 281), Vicens Vives (1961, 223 y 253), Reglá (1968, 47), etc.

Desgraciadamente unos y otros al tratar el tema están pensando en Aragón, asociando el problema en Valencia.

Sin menoscabo de lo dicho hasta ahora, procedamos a aclarar el estado de la cuestión en el contexto contestano. En primer lugar debemos formularnos la pregunta: ¿Quiénes eran los exáricos?, por inercia contestaríamos: unos mudéjares que...». Nos plazca o no, la respuesta no resulta tan sencilla, pues en 1303 Bernat de Fraga dice ser exárico de Domingo de Cepillo y en 1305 , en otro documento, Bernat Sala se declara exárico de Sánchez de Gracia (A. M. C. $1303,32 v ; 1305,73 v$ y 107).

Ante estas pruebas no tenemos más remedio de aceptar que tanto cristianos como mudéjares podian serlo, aunque bien podriamos intentar buscar una justificación, es decir, considerar a estos personajes como cristianos nuevos que adoptan dichos nombres al bautizarse. Lamentablemente tenemos pocas noticias sobre su vida en la villa, sabemos que en 1303 aparece Sala como vecino de la villa y que murió en 1314 dejando una hija de nombre Beneyta de corta edad (A. M. C. 1314, 63). Del segundo carecemos de noticias, pero tanto en uno u otro no parece viable su reciente conversión, por tanto no hay más remedio que aceptar lo dicho, dejando abierta una hipotética puerta sobre su ascendencia musulmana.

Continuando con el análisis, parece aceptado que el exárico es un agricultor que explota las tierras de un señor. Tal afirmación resulta incompleta. Si bien el exárico puede trabajar los campos, también puede se ganadero. En 1303 (Fol. 32v) Domingo de Cepillo pone en "exariquia» una cerda con cuatro crías, repartiéndose a partes iguales beneficios y gastos con Bernat de Fraga. Por tanto debemos aceptar que el contrato, además de agrario, puede ser ganadero.

Se ha firmado que el exárico tiene disminuida su capacidad legal. Este extremo parece apuntarse durante el proceso aludido anteriormente entre Alí y Ramón (Aracil 1983, 80-1; A. M. C. 1275, 42). Ante la sucesión de demandas formuladas por las partes, el justicia nombra a Juan de Vitoria, curador de la persona y bienes de Ali. Sabemos que hay necesidad de nombrar curador cuando la persona es menor de edad, circunstancia que aquí parece no 
darse; cuando se pierde la razón o se malgasta la hacienda, extremos igualmente descartables y cuando se carece de la capacidad jurídica para llevar las demandas. Creemos que éste sería el caso, no porque Alí no haya disfrutado de ella, sino porque durante la vigencia del contrato, no posee la capacidad completa para litigar con terceros y menos contra su señor.

En apoyo de esta afirmación recurrimos una vez más al proceso entre Alí y Ramón. Este último presenta varios testigos, unos cristianos y otros mudéjares. Los testimonios de los cristianos fueron rechazados por Alí aduciendo que éstos, según los fueros, no pueden dañar a mudéjar, pero al mismo tiempo rechaza el testimonio de un mudéjar por estimar que es «muçaquis» de Ramón. Pensamos que por estar vinculado a Ramón no podía testificar en pleito donde su señor fuese parte interesada o que su declaración no puede tenerse en cuenta por no reunir la capacidad jurídica necesaria (A. M. C. 1275, $4 \mathrm{v}$ y $13 \mathrm{v}$ ). En otro lugar Abrahaym se obliga a pagar a Domingo de Cepillo cierta cantidad si no presenta ante el Justicia a Mohamet Achulani y a Alí Axatini, exáricos de Domingo Cepillo, posiblemente sin su consentimiento (A. M. C. 1295,4 V).

Hubiese resultado interesante el haber podido interrogar a Alí Allobadi sobre si se consideraba o no exárico de Ramón. Durante el proceso se presenta casi la ocasión, cuando el justicia le pregunta si bebió vino en la taberna. Alí responde que no fue él, sino el exárico de Ramón. Podriamos interpretar estas palabras como que Alí nunca se consideró exárico de Ramón, o que había dejado de serlo por rescindir el contrato. Creemos que es más factible lo primero (A. M. C. 1275, 10v).

Finalmente debemos preguntarnos ¿se es exárico a perpetuidad? parece que no y así nos lo hace saber Bernat Sala. Al ser requerido por el justicia cuando ocurrió cierto hecho, él respondió que cuando era exárico de Sánchez de Gracia (A. M. C. 1305, 73v).

En conclusión podemos definir a los exáricos "como mudéjares o cristianos que establecian un contrato de aparcería por varios años sobre un predio o ganado durante el cual el propietario cedia el terreno y pate de la simiente, mientras el aparcero aportaba el resto, los animales de labor y sus manos, repartiéndose la cosecha en la proporción acordada y viendo disminuida su capacidad jurídica y de movimiento mientras estuviese vigente».

Con estas líneas no pretendemos hacer una exposición definitiva del tema, pero sí estimular a los estudiosos a profundizar en un aspecto tan interesante de nuestra historia. 
La primitiva "Qustantaniya» musulmana debió de hallarse ubicada sobre la ladera oriental del cerro del castillo, entre la actual calle de la Santísima Trinidad, el lienzo occidental de la muralla y la zona llamada de la Costa, a tenor de los restos cerámicos encontrados en dicho lugar (Ferrer Marset 1984).

¿Se hallaba bajo la protección de una línea amurallada? La cuestión es difícil de contestar. Las crónicas de la época nada dicen al respecto (Malo de Molina 1857, 135-6). Podría darse el caso de que el núcleo musulmán estuviera exclusivamente protegido por el castillo y el alcázar, aunque sobre este último no estamos en condiciones de asegurar su existencia, tan sólo se han localizado restos de muros musulmanes en las recientes obras de reconstrucción. Asegurada la protección de las partes más vulnerables, el resto se dejaba en manos del relieve: por el sur, un pronunciado barranco descendía desde el cerro por la calle Santísima Trinidad y moría en el barranco del Alberri; por el norte, una pronunciada pendiente, hacía lo propio. No se descarta la posibilidad de que, al menos, por su parte oriental estuviese protegida por murallas, que posteriormente podian haber servido como lienzo occidental de las murallas de la villa cristiana.

Durante los repartimientos de 1248-9, los cristianos heredados en Cocentaina recibirán casas y tierras en ella o en sus alquerías. Por tanto, el primer asentamiento cristiano se produjo en las propias viviendas desocupadas de los antiguos propietarios musulmanes ahora exiliados.

Esta distribución entrañaba serios peligros para la reducida comunidad cristiana que era necesario abordar cuanto antes, pues la convivencia de las dos comunidades sobre un mismo solar no resultaba, en unos momentos tan críticos, aconsejable. El primer paso lo dio Jaime I fundando el arrabal como residencia exclusiva de los musulmanes contestanos. La fecha nos es desconocida, Agustín Arques recoge la noticia pero sin datarla. Pensamos que debió de ser antes de 1260, pues un documento fechado el 13 de febrero de 1260 alude a la separación de ambas comunidades (A. C. A. 11, 193).

Esto no implica que se tratase realmente de una nueva fundación, en el sentido material de la palabra, ya que alrededor de la mezquita del arrabal se han localizado restos cerámicos de siglos anteriores, lo que da pie a pensar en la existencia de un primitivo núcleo de población, quizás la alquería de «Atech», cuyo nombre desaparece, significativamente, de los topónimos posteriores al momento del repartimiento. Este lugar, ampliado con el asentamiento de la antigua población de la villa musulmana, dará lugar al arrabal o moreria de Cocentaina. 
Agustín Arques (Manuscrito IV, 18v) se decanta por relacionar la fundación con la construcción de nueva planta, por ello la denomina "vila nova» a la zona ocupada por los mudéjares, es decir, al arrabal, pensando que los cristianos permanecerían instalados en la vieja villa musulmana.

Por el contrario, nosotros pensamos con Pierre Guichard (III, 1980, 84) que los cristianos tuvieron una tendencia a abandonar los incómodos asentamientos musulmanes, creando nuevos núcleos o "vila nova" en lugares más apropiados, por tanto, la fundación hay que entenderla, más que desde el punto de vista material, como una institución jurídica.

\section{RGANIZACIÓN JURIDICA DE LA ALJAMA CONTESTANA}

Las aljamas mudéjares conservaron sus antiguos funcionarios islámicos, pero por influencia de las instituciones cristianas fueron adoptando competencias similares a los funcionarios municipales de los núcleos cristianos.

\section{a) El alcadi}

"Las competencias del alcadí mudéjar no parece que variaran mucho con respecto a esta institución islámica. A él competía la vigilancia y control oficial de la propiedad colectiva, es decir, los hacibes o donaciones piadosas a la mezquita; el cometido de juez y notario y las atribuciones propias de su cargo, como matrimonios y repudios, sucesión o herencia, la situación de los huérfanos, los contratos y el castigo de los criminales» (Barceló 1984, 59). Para tan vastas competencias se requería la colaboración de varios subalternos y escribanos.

Los mudéjares fueron autorizados de acuerdo con los términos de la capitulación, a seguir rigiéndose según la «çunna» musulmana. Con el fin de que entendiese en todas las causas civiles de acuerdo con sus propias leyes, Jaime I creó en 1273 un gran distrito con centro en Cocentaina y que comprendía Planes, Gallinera, Alcalá, Penáguila, Guadalest, Polop y Tárbena, con sus términos y alquerías, al que dotó de un juez común para todos nombrado para dicho cargo a Mohamat Abenhalaiar, alcadí de Cocentaina, pudiendo recurrir sus sentencias ante el alcadi de Xátiva (A. C. A. 19, 18).

El alcadí administraba justicia al estilo de las autoridades cristianas. Presidía un tribunal constituido por el alamín, el zalmedina y los "vells» musulmanes. Con el asesoramiento y conformidad de estos dictaba sentencia (Roca 1952, 129).

En principio, las causas criminales se incoaban ante la Corte cristiana, lo que les proporcionaba sustanciosos beneficios por las sentencias dictadas, 
pero en 1264 el rey les concedió la gracia a los musulmanes de Cocentaina de recurrir ante el baile, y no ante la justicia, en estos casos (Roca 1952, 191). No debe ser interpretada la medida como una consecuencia de su política de protección al mudéjar, sino, como hemos dicho, son móviles económicos los que inducen al rey a concederles dicho privilegio (Mateu 1952, 31).

Pese a esta clara delimitación de competencias, en la Cort cristiana continúan incoándose causas por deudas, herencias, etc. habidas entre mudéjares y que deberían, a todas luces, competir al alcadí. No se crea que se trata de una usurpación de funciones promovida por el justicia, sino que son los mismos interesados quienes acuden voluntariamente ante él (A. M. C. 1269, 3) y pensamos que la razón se justificaría en su mayor efectividad para obtener satisfacciones en causas entre vecinos de diferente localidad.

Cuando los litigantes pertenecen a diferentes comunidades, cristiana y musulmana, el asunto incumbe al justicia, pero disponemos de un caso, ya mencionado anteriormente, en el que el alcadi de Cocentaina, Mohamet Hibnabihayr, sentencia en el contencioso habido entre Ramón de Canet y Alí Allobadi en presencia del justicia (A. M. C. 1275, 22v, 26v y 30v).

De todos los posibles mudéjares que detentaron el cargo de alcadí de Cocentaina a lo largo del siglo XIII tan sólo conocemos el nombre del arriba indicado y ello se debe, en gran medida, a que cuando se alude a su persona no se hace constar su nombre, sino solamente el cargo.

\section{b) El zalmedina}

«Juez en primera instancia y carcelero, encargándose de los fraudes (capciones), la prisión (alhapz) y el nombramieno de policías (exortivos) que le ayuden a ejercer la justicia» (Barceló 1984, 53). De este modo se conseguia aligerar el trabajo del alcadí.

En Cocentaina carecemos de noticias sobre su actuación, no hemos hallado ninguna cita documental durante los siglos XIII y XIV a pesar de constar su existencia en un privilegio del 14 de julio de 1275 por el que Jaime I nombra a Abduluhabeb Albini zalmedina de los sarracenos del arrabal de Cocentaina (A. C. A. 20, 270v).

c) El alamín

La población mudéjar requería de una organización administrativa semejante a la cristiana por lo que el rey Jaime instituyó a los alamines.

El alamín es un funcinario mudéjar que sirve de enlace entre las aljamas locales autóctonas y las autoridades reales. Empezó siendo un simple recaudador de impuestos reales y eclesiásticos (Barceló 1984, 94) pasando, con 
el tiempo, a ser gobernador efectivo y la figura central del sistema político mudéjar (Burns 1981, 264). Con la incorporación de estos territorios al Reino de Valencia, el alamín sufrió la influencia institucional cristiana, asimilándose a la noción jurídica de baile, lo que representó, en sí, un aumento de su poder real. Paulatinamente los aljamas fueron organizándose al estilo de los municipos cristianos.

El alamín del arrabal de la villa sólo ostentó su jurisdicción sobre dicho lugar, no sobre las alquerías y demás lugares del término contestano, ya que en cada uno de dichos lugares y alquerías había un alamín que representaba a su comunidad islámica, así por ejemplo los encontramos en La Alcudia, alquería del Perro, etc. (A. C. A. 82, 69).

Desde 1269 a 1275 y posiblemente antes y después de esas fechas, el cargo fue desempeñado por Alí Uharathatab. En 1277 lo regentó Abrahim Annaqy y en 1294 aparece como tal Mohamat Abn Omar, que al igual que el primero bien pudo desempeñarlo antes y después de esa fecha (A. M. C. 1269, 1v; 1275,$30 ; 1277,9 v$ y $1294,12 v)$.

\section{d) El moixerif (almojarife)}

Nombre de clara raíz árabe, representa a un funcionari que se ocupa del cobro de las rentas reales, del pago de las deudas asignadas a dichas rentas y de todo aquello que se refiera a la recaudación fiscal (Garcia de Valedeavellano 1973, 673).

Puede existir una almojarife cuya jurisdicción se extienda por una amplia zona, como la de la Montaña al sur del Júcar y a la cual pertenece Cocentaina (Burns $1981,462-8$ ) y otro que se ocupa de una pequeña población y cuyos cometidos se interfirieren con los del alamín; éste sería el caso del almojarife de la alquería del Perro (A. C. A. 82, 69). En Cocentaina nos resulta completamente desconocido.

\section{CONTRIBUCIÓN FISCAL DE LA MORERÍA CONTESTANA}

Las comunidades musulmanas y algunos de sus miembros contribuyeron a las arcas reales por el sistema de acuerdo o de avecinamiento previo (Burns 1981, 468).

«El musulmán suele estar obligado a utilizar los monopolios señoriales y a pagar ciertos derechos por su uso. Son estos los hornos, molinos, tiendas - taberna, carnicería, almacera... También están sometidos a impuesto ciertos servicios o uso de bienes, como son la alcaldía o alcaidía, esto es, la custodia del castillo señorial, las casas, mezquitas, el agua, obradores, barcas... 
El sector agropecuario... está gravado por una serie de derechos que, en general, son los pechos sobre la tierra, a veces llamados almagram o alfarda, las gallinas, las colmenas...". "A todos estos derechos hay que añadir también la azofra o çofra y una serie de servidumbres... el morabatí, cabezaje o alfetra, besant, millarès..." "En el concilio provincial de Lérida de 1293 se acuerda que... los musulmanes, en tierras de señores cristianos, deben abonar el diezmo a la lglesia, estando obligados también al pago de primicias...» (Barceló 1984, 88 y 100-1). Creemos que estas líneas resumidas nos permiten hacernos una idea sobre el complicado sistema fiscal.

El 24 de septiembre de 1257 tuvo lugar la primera contribución conocida de las aljamas mudéjares del Reino de Valencia. Cocentaina estuvo al margen sin que sepamos las causas, pero posiblemente se deba a efectos de la revueta (Chabas 1886,255$)$. Al año siguiente ya aparecen gravadas algunas alquerías con el impuesto del besante (Gual 1949, 188) y las "sofras de aga y madera" a todos los mudéjares de Cocentaina y Alcoy, de sus castillos y regiones (Burns 1981a, 458).

Unos años después, en 1269, el arrabal parece que aún no se ha repuesto de los efectos de la primera revuelta. La corona arrienda sus rentas a Rodrigo Martiez de Azagra y a Pedro Diez por la cantidad de 2.000 sueldos anuales pagaderos por mitades en agosto y enero, pero con el compromiso de duplicar las rentas al cabo de ese períod so pena de 2.000 y 1.000 sueldos de sanción respectivamente (A. C. A. 15, 136). La ausencia de noticias nos impiden conocer si dicho objetivo fue alcanzado. Creemos que a nivel general existía una honda preocupación por mejorar la gestión y recaudación de las rentas, como se hace notar en 1282 cuando la corona emprende la reforma de las morerías y para ello faculta a Pedro de Libiano a que tome las medidas pertinentes y exhorta a todos para que colaboren con él (Burns 1981, 464).

En 1283 el arrabal contribuyó con 2.000 sueldos más 100 del impuesto de la cena, lo que parece indicar que las rentas no mejoraron en los niveles deseados. La alfarda de 1286 no representa más que 200 sueldos, como en Alzira, lo que le permite a P. Guichard afirmar que tras la expulsión de los mudéjares la aljama contestana vio reducida enormemente su población (A. C. A. 51, 15) (Guichard III 1980, 62).

\section{MODO DE CONCLUSIÓN}

Realizada la letura de este modesto estudio podemos tener la sensación de dejar todo en el aire, verdaderamente nada definitivo podemos decir, pe- 
ro lo importante es, por una parte, contribuir en algo al mejor conocimiento del mudejarismo valenciano, y por otra, iniciar su estudio a nivel contestano.

Los musulmanes devinieron en mudéjares con su sumisión a los cristianos y con ello tuvo que producirse, se quiera o no, los primeros cambios provocados por los nuevos señores. Pensamos que en principio debieron de ser poco significativos, pero con la consolidación de la conquista, la reducción de las revueltas y la apertura del proceso colonizador la situación fue generacionalmente degradándose, pese a lo que apunten las cartas-puebla, de las cuales, la nuestra nos es desconocida.

La falta de una suficiente documentación hace que, proceder a un estudio intensivo de los mudéjares contestanos resulte demasiado aventurado. Creemos que tan interesante problemática hay que insertarla dentro del contexto general del Reino de Valencia; en Cocentaina debieron de darse situaciones comunes a todo el Reino, pero, al mismo tiempo, la realidad contestana debió deferenciarse de la castellonense (por nombrar un ejemplo). Su situación de frontera, su marco geográfico y la convivencia con los colonos cristianos tuvo que dar lugar a unas peculiaridades que habría que sacar a la luz. Para ello hace falta una proliferación de estudios locales en los que se comparase la realidad con la legalidad llegando así a una valoración media.

A ese afán por conocer la situación socio-económica de los mudéjares obedece el apartado sobre los «exáricos». Muy pocos han prestado atención al problema, bien por desconocimiento, bien por falta de documentación, bien por creerlo reservado al valle del Ebro, a pesar de la importancia que de hecho tiene.

La segunda mitad del siglo XIII debió de ser una época de cambios poco significativos, pero que inexorablemente iban royendo los cimientos de las cartas-puebla. Al final del siglo y durante el XIV la situación podía resultar extraña para un mudéjar de la primera generación. Lentamente se habia generado una nueva forma de vida a los antiguos pobladores valencianos. Hay que continuar investigando en los archivos locales y dando a conocer los resultados con el fin de poder avanzar en un mejor conocimiento del mudejarismo. 


\section{BIBLIOGRAFÍA}

ARACIL, Rafael y otros (1983): "Els estudis d'historia agraria al Pais Valencià, I Col.loqui d'historia agraria, octubre de 1978, Valencia, p. 79-118.

ARCHIVO DE LA CORONA DE ARAGÓN (A. C. A.) Registros del sigio XIII.

ARCHIVO MUNICIPAL DE COCENTAINA (A. M. C.) Libros de la Cort de Justicia del siglo XIII. ARCHIVO PARROQUIAL DE SANTA MARIA. Cocentaina. Agustín Arques, Manuscrito IV.

AUREUM OPUS... (1972) Valencia.

BAER, Yitzhak (1981): «Historia de los judios en la España cristiana» I. Desde los origenes hasta el final del S. XIV. Madrid.

BAÑO ARMIÑANA, R. (1980): «Registres de Jaume la l'Arxiu Municipal de Cocentainan, IDEA 29. BARCELÓ TORRES, Carme (1984): «Minorias islámicas en el País Valencia. Historia y dialecto», Universidad de Valencia.

BURNS, R. I. (1975): «Medieval Colonialism: Post Crusader Exploitation of Islamic Valencia». Princeton University Press.

- (1977): «/slam under the Crusaders: Colonial survival in the Thirteenth-Century Kingdom of Valencia", Princeton University Press.

- (1981): "Jaume $1 \mathrm{i}$ els valencians del s. XII", Valencia.

- (1981a): «Los mudéjares de Valencia: temas y metodología». I Simposium Internacional del Mudejarismo, p. 453-98

- (1982): «El reino de Valencia en el siglo XIIl", Valencia.

CAGICAS, Isidro de las (1948-9): “Los mudéjares. (Minoría étnico-religiosa de la Edad Media Española)", Madrid.

CISCAR PALLARES, E. (1977): “Tierra y Señorio en el País Valenciano (1570-1620)», Valencia. CHABAS I LLORENS, R. (1866): Revista el Archivo, Denia.

EPALZA, M. de y LLOBREGAT, E. (1982): « ¿Hubo mozárabes en tierras valencianas? Proceso de islamización del Levante de la Peninsula (Sharq-Al-Andalus)s, IDEA 36, p. 7-32.

FERNÁNDEZ y GONZÁLEZ, F. (1866): «Estado social y político de los mudéjares de Castilla, considerados en si mismos y respecto de la civilización española", Madrid.

FERRER MARSET, P. (1984): “Aportacions per a la cronologia de les construccions medievals del castell de Cocentaina", Rev. Moros y Cristians, Cocentaina.

FERRER NAVARRO, R. (1982): "La repoblación de una comarca alicantina", Anales Universidad de Alicante $n .^{\circ}$ 1, 9.27.

FURIO, Antoni (1982): "Camperols del Pais Valencia", Valencia.

FURIO, A. Y GARCIA, F. (1983): "El feudalismo medieval valencia: un assaig d'interpretació", Debats $n .^{\circ} 5$.

FUSTER, Joan (1962): «Nosaltres, els valencians», Barcelona.

GARCÍA DE CORTÁZAR, J. A. (1975): "Nueva historia de España en sus textos», Santiago. 
GARCIA DE VALDEAVELLANO, Luis (1973): «Curso de historia de las Instituciones Españolas», Madrid.

GARCÍA y SANZ, A. (1961): «El censal», BSCC XXXVII, 281.

GIL OLCINA, Antonio (1979): «La propiedad señorial en las tierras valencianas», Valencia.

GISBERT y SÁNCHEZ DE LA VEGA, R. (1950): «Los contratos agrarios en el derecho medievalm, Bol. Universidad de Granada XXII, 305-330.

GONZÁLEZ PALENCIA, A. (1945): "El régimen de riegos de Veruela", Al-Andalus X,

GUAL CAMARENA, M. (1949): “Mudéjares valencianos, aportaciones para su estudio», Saitabi VII, 165-199.

GUICHARD, Pierre (1980): “Nuestra Historia», Ill-IV, Valencia.

HILTON, Rodney H. (1978): "Siervos liberados. Los movimientos campesinos medievales y el levantamiento inglés de $1381 \%$, Madrid.

HINOJOSA, E. (1904): «Mezquinos y exáricos», Zaragoza, 523-531.

LEVI-PROVENÇAL, E. (1965): «España musulmana», tomo V Historia de España de Menéndez Pidal, Madrid.

MALO DE MOLINA, M. (1857): «Rodrigo el Campeador», Madrid.

MARTÍNEZ FERRANDO, J. E. (1963): “La Valencia de Jaime I", Valencia.

MATEU y LLOPIS, Felipe (1952): “La repoblación musulmana del Reino de Valencia en el siglo XIII y las monedas de tipo almohade", BSCC, 29-43.

NAVARRO REIG, J. (1985): "Los origenes de la Cocentaina cristiana", Rev. Moros y Cristians, Cocentaina.

PLA ALBEROLA, P. (1982): "Acerca de los contratos agrarios de los mudéjares valencianos: los capitols de Catamarruc", Anales Universidad Alicante, 119-138.

REGLA, Joan (1968): "Aproximació a la História del Pais Valenciá», Valencia.

PILES ROS, Leopoldo (1970): "Estudio documental sobre el bayle general de Valencia: su autoridad y jurisdicción”, Valencia.

RENOUVARD, Yves (1962): «Les principaux aspects économiques et sociaux de l'histoire del pays de la Courounne d'Aragon aux XII-XIII et XIV siècle", CHCA VII, I, p. 231-264.

ROCA TRAVER, F. A. (1951): "La gobernación foral del reino de Valencia: una cuestión de competencias", EMA IV, 176-214.

115-208.

- (1952): "Un siglo de vida mudéjar en la Valencia medieval (1238-1338)", EMA V,

SANCHIS LLORENS, R. (1972): «Aportaciones de Alcoy al estudio de la esclavitud en el Reino de Valencia", Alcoy.

TORRES FONTES, Juan (1961): "Los mudéjares murcianos en el siglo XII"», Murgetana XVII, 57-81.

VALDEON, Julio y otros (1982): «Feudalismo y consolidación de los pueblos hispánicos (s. XIIXV)", Vol. IV Historia de España de Tuñón de Lara, Barcelona.

VERLINDEN, Charles (1934-5): "L'esclavage dans le monde Iberique Medieval", AHDE XI, p. 283-448 y XIII, p. 361-424.

VICENS VIVES, Jaime (1961): «Historia de España y América», II, Barcelona 